Personalidade Acadêmica Homenageada:

Augustus B. Cochran III (Agnes Scott College)

\title{
CLÁUSULAS DE NÃO CONCORRÊNCIA NOS CONTRATOS DE FRANQUIA: OBSERVÂNCIA DOS DEVERES ANEXOS AO CONTRATO x LIBERDADE DE INICIATIVA
}

\section{NON-COMPETITION CLAUSES IN FRANCHISE CONTRACTS: OBSERVANCE OF DUTIES ATTACHED TO CONTRACT x INITIATIVE FREEDOM}

\begin{abstract}
AMANDA CRISTINA PAULIN
Professora de Direito Civil e Processo Civil no Centro Universitário Curitiba UNICURITIBA. Curitiba - PR. Mestranda em Direito Empresarial e Cidadania no Centro Universitário Curitiba - UNICURITIBA. E-mail: amandapaulin@yahoo.com.br
\end{abstract}

\section{ANNA CHRISTINA GONÇALVES DE POLI}

Professora de Direito Empresarial no Centro Universitário Curitiba - UNICURITIBA. Mestre em Direito pela PUC/PR. Advogada. E-mail: anna.poli@pnsa.adv.br

\section{RESUMO}

A presente pesquisa visa estudar a relação entre franqueador e franqueado não apenas durante a execução do contrato, mas, com o recorte dos aspectos póscontratuais, ou seja, investigar a existência - e exigibilidade - de deveres de não concorrência entre os pactuantes de um contrato de franquia após o encerramento do vínculo.

A existência da vedação à concorrência posterior ao encerramento do contrato de franquia pode conflitar com o direito fundamental à livre iniciativa, o que requer o juízo de ponderação entre os valores, em uma clara utilização das lições de 
Personalidade Acadêmica Homenageada:

Augustus B. Cochran III (Agnes Scott College)

Robert Alexy. Assim, tem-se como problema geral da pesquisa a ser desenvolvida o estudo da aplicabilidade e limites das cláusulas de não concorrência aos contratos de franquia, ante a dificuldade da sua plena definição e aplicação, dada a necessidade de fazer a leitura de tais pactos a partir de uma perspectiva civil-constitucional. Como questão específica tem-se: quais os limites das cláusulas de não concorrência, de acordo com o estabelecido no artigo $3^{\circ}$ da lei 8.955/94, conhecida como "Lei de Franquias" ou "franchising"?

O estudo a ser desenvolvido contará com a revisão bibliográfica sobre o tema, em uma abordagem analítica e crítica, com o objetivo de responder as perguntas colocadas, além de uma análise da aplicação do princípio da boa-fé aos contratos empresariais. Como apoio ao desenvolvimento teórico, será feito estudo de caso, iniciando-se com análise do denominado "Caso da Cia. Nacional de Tecidos Juta". A doutrina previamente selecionada afirma que a boa-fé objetiva, conceituada como exigência de conduta leal dos contratantes, está relacionada aos deveres anexos, que são decorrentes de qualquer negócio jurídico, não havendo sequer a necessidade de previsão no instrumento negocial. A quebra desses deveres anexos ou secundários causa a violação positiva do contrato, o que pode atrair o dever de indenizar.

Além de investigar se a violação ao dever de não concorrência caracterizara uma violação positiva do contrato, é necessário fazer o cotejo com a liberdade de iniciativa assegurada na Constituição Federal. Como resultados esperados tem-se a indicação da prevalência de valores constitucionais, bem como da interpretação dos contratos empresariais segundo os ditames da boa-fé, com respostas às eventuais modulações no alcance deste princípio.

PALAVRAS-CHAVE: Direito da Concorrência; Franquia; Deveres anexos; Liberdade de iniciativa.

\section{REFERÊNCIAS}

ASCENSÃO, José de Oliveira. A desconstrução do abuso do direito. In: DELGADO, 
Personalidade Acadêmica Homenageada:

Augustus B. Cochran III (Agnes Scott College)

Mário Luiz; ALVES, Jones Figueiredo. Novo Código Civil: Questões controvertidas. Série grandes temas de direito privado. São Paulo: Método, 2005.

AZEVEDO, Antonio Junqueira. Negócio jurídico: existência, validade e eficácia. São Paulo: Saraiva, 2014.

JUNIOR, Antonio Jorge Pereira; SANTOS, Ivanna Pequeno dos. BOA-FÉ OBJETIVA NOS CONTRATOS EMPRESARIAIS: O CASO DA CIA NACIONAL DE TECIDOS DE JUTA. Revista Jurídica UNICURITIBA, [S.I.], v. 52, n. 3, p. 68 - 85, jul. 2018. ISSN 2316-753X. Disponível

em: $<$ http://revista.unicuritiba.edu.br/index.php/RevJur/article/view/3048>. Acesso em: 04 jun. 2019.

JÚNIOR, Marcos Augusto de Albuquerque Ehrhardt; TORRES, Marcio Roberto. Direitos Fundamentais e as Relações Privadas: Superando a (Pseudo) Tensão entre Aplicabilidade Direta e Eficácia Indireta para Além do Patrimônio. Revista Jurídica UNICURITIBA, [S.I.], v. 53, n. 4, p. 326 - 356, out. 2018. ISSN 2316-753X. Disponível em: <http://revista.unicuritiba.edu.br/index.php/RevJur/article/view/3222>. Acesso em: 04 jun. 2019.

MARTINS-COSTA, Judith. A boa-fé no direito privado. São Paulo: Revista dos Tribunais, 1999.

SILVA, Clóvis V. do Couto e. A obrigação como processo. Rio de Janeiro: FGV, 2006.

TARTUCE, Flavio. Direito Civil: teoria geral do contratos e contratos em espécie. v.3. 12 ed. Rio de Janeiro: Forense, 2017. 